\title{
The effect of soybean extract supplementation to tris aminomethane-egg yolk extender on the post-thawing quality of Simmental semen
}

\author{
Sri Wahjuningsih*1), Muhammad Nur Ihsan ${ }^{1)}$, Aulia Puspita Anugra Yekti ${ }^{1)}$, Muhammad \\ Agus Tahar ${ }^{1)}$ \\ 1) Faculty of Animal Science, Brawijaya University, Jl. Veteran, Ketawanggede, Kec. \\ Lowokwaru, Kota Malang, Jawa Timur, Indonesia, 65145
}

Submitted: 07 October 2020, Accepted: 30 November 2020

\begin{abstract}
This research aimed to evaluate the effect of soybean extract (Glycine max (L.) Merr.) supplementation to tris aminomethane-egg yolk extender on the post-thawing quality of Simmental bull frozen semen. The fresh semen was collected twice a week from 3 Simmental bulls aged 3 to 3.5 years by using artificial vagina. The semen was then selected for sperm motility and abnormality. Semen that had $>70 \%$ motility and $<15 \%$ abnormality, was used for the research. The research was conducted in a completely randomized design with 4 treatments and 30 replications. The research treatments include $0 \%$ (T0), $7.5 \%$ (T1), $10 \%$ (T2), and $12.5 \%$ (T3) soybean extract supplementation to tris aminomethane-egg yolk extender. The observed variables include spermatozoa motility, viability, abnormality, and plasma membrane integrity. The collected data were analyzed with ANOVA and followed with Duncan's Multiple Range Test to determine mean differences. The results showed that soybean extract supplementation gave significant effect $(\mathrm{P}<0.05)$ on the post-thawed quality of Simmental semen. The research concludes that $10 \%(\mathrm{v} / \mathrm{v})$ soybean extract supplementation to tris aminomethane egg-yolk extender was effective to maintain sperm motility, viability, and plasma membrane integrity of the post-thawed Simmental semen.
\end{abstract}

Keywords: Bull; Soybean extract; Frozen semen; Motility; Viability; Plasma membrane integrity

\footnotetext{
*Corresponding Author: yuning@ub.ac.id
} 


\section{INTRODUCTION}

Artificial insemination (AI) has been known as an effective method for cattle farm breeding management, both on industrial and small-scale level, due to its practicality and high success rate. However, the succesful insemination highly depends on the post-thawed semen quality, which found to be a problem commonly found on the small-scale cattle farm, considering the limited capital and facilities. One of the approaches that can be used to tackle this problem is to apply an effective and efficient semen extender which could maintain frozen semen quality prior to be used for insemination. Tris aminomethane- egg yolk extender is one of the widely used semen extenders, which had shown the ability to maintain semen $\mathrm{pH}$ and shelf life of bull semen during cryopreservation $\left(-196^{\circ} \mathrm{C}\right)$. Tris contained fructose and citrate which could prevent $\mathrm{pH}$ alteration due to lactic acid production by spermatozoa, while also maintain osmotic pressure and electrolytes stability, aside from providing energy. Moreover, egg yolk contains lipoproteins and lecithin that would act as extracellular cryprotectant.

Research has shown that cryopreservation could decrease spermatozoa qualities due to the experienced cold shock (Wahjuningsih, et al., 2019). Rahayu et al. (2014) showed that the damaged spermatozoa plasma membrane contributes to the higher mortality, in which could be prevented with lecithin supplementation. Soybean is one of natural sources for lecithin and the soybean extract supplementation is believed to be able to protect spermatozoa from cold shock. Soybean contained $1.49 \%$ to $3.08 \%$ lecithin, higher than peanut which is around $1.11 \%$. Lecithin has the membrane coating properties by maintaining the phospholipid bilayer configuration of the spermatozoa (Rezki et al., 2016). The phospholipid of the egg yolk and lecithin of the soybean would not penetrate and alter spermatozoa plasma membrane, but instead formed a protective layer against extracelullar damage (Ariantie et al., 2013).The progressive sperm motility, viability and plasma membrane integrity evaluation has been then used as general indicator for semen quality. In this research, the supplementation of soybean (Glycine $\max$ (L.) Merr.) extract to tris aminomethane-egg yolk extender were observed to determine its effect toward postthawed Simmental bull semen qualities.

\section{MATERIALS AND METHODS Semen Collection}

The semen used in this research was obtained from 3 Simmental bulls at the age of 3 to 3.5 years, weighed at 665 to $672 \mathrm{~kg}$, and reared intensively at Artificial Insemination Center, Ungaran, Indonesia. The semen was collected twice a week using artificial vagina, and the collected semen was selected based on semen motility $(>70 \%)$, viability $(>70 \%)$, mass motility $(2+)$, and abnormality $(<15 \%)$ to be used for the research.

\section{Tris Aminomethane-egg Yolk and Soybean Extender}

The production of tris aminomethaneegg yolk was done by following the method described by Wahjuningsih et al. (2019). As much as $2 \mathrm{~g}$ of soybean was added with 100 $\mathrm{ml}$ distilled water and heated in hot plate magnetic stirrer $\left(100^{\circ} \mathrm{C}, 6\right.$ speed $)$ for 15 minutes. The produced supernatant was then used for the research.

\section{Macroscopic Observation}

The macroscopic observation of fresh semen qualities included semen volume, color, and $\mathrm{pH}$. The direct observation was done to measure the semen volume, colour, smell, while semen $\mathrm{pH}$ was observed by using $\mathrm{pH}$ meter.

\section{Microscopic Observation}

The microscopic observation included spermatozoa concentration, mass motility, individual motility, viability, plasma membrane integrity and abnormality. The mass motility was observed by following the method described by Arifiantini (2012), while individual motility was observed 
using microscope at 400x magnification (Lukman et al., 2014). The semen viability and abnormality were observed by using eosin-negrosin staining observation. The spermatozoa were observed under 400x magnification and stained spermatozoa indicate dead cell (Ducha et al., 2012). The membrane integrity was observed by placing diluting $50 \mu \mathrm{L}$ semen with $400 \mu \mathrm{L}$ hypo-osmotic solution in an eppedorf tube, and followed with $30 \mathrm{~min}$ incubation at $37^{\circ} \mathrm{C}$. The spermatozoa membrane cell integrity was then observed under microscope with 400x magnification (Karunakaran et al., 2017).

\section{Experimental Design and Data Analysis}

The research was conducted in a completely randomized design with 4 treatments and 30 replications. The research treatments were soybean extract supplementation at $0 \%$ (T0); $7.5 \%$ (T1); $10 \%$ (T2); and $12.5 \%$ (T3) to the base semen extender $(80 \%$ Tris aminomethane and $20 \%$ egg yolk). The data were then analyzed using analysis of variance (ANOVA) and followed with Duncan's Multiple Range Test to determine mean differences among treatments.

\section{RESULT AND DISCUSSION Fresh Simmental Bull Semen Qualities}

Prior to be added with semen extender, the fresh Simmental bull semen qualities were evaluated through macroscopic and microscopic observations. The results of fresh semen evaluation is presented in Table 1.

Table 1. Fresh Simmental bull semen observation

\begin{tabular}{lc}
\hline \multicolumn{1}{c}{ Parameters } & Mean \pm SD \\
\hline Volume $(\mathrm{mL})$ & $7.21 \pm 0.42$ \\
Color & Milky white \\
$\mathrm{pH}$ & $6.59 \pm 0.20$ \\
Concentration $\left(10^{6}\right.$ cell $\left./ \mathrm{mL}\right)$ & $1459.80 \pm 123.22$ \\
Mass sperm motility & +++ \\
Individual sperm motility (\%) & $80.75 \pm 5.50$ \\
Viability (\%) & $86.75 \pm 6.53$ \\
Plasma membrane integrity (\%) & $84.35 \pm 6.75$ \\
Abnormality $(\%)$ & $6.81 \pm 0.85$ \\
\hline
\end{tabular}

The semen volume is known to be affected by several factors, i.e., bull age, physical condition, environment, and technical skill of the inseminator. Ismaya (2014) further elucidates that age would affect testicle size, which increased the seminiferous tubules along with increased age and thus resulted with higher semen production until reached certain age.

The average Simmental bull semen $\mathrm{pH}$ in this research was $6.59 \pm 0.20$ and categorized as normal. The mass and individual spermatozoa motility of fresh semen in this research were categorized as normal and fulfilled the requirements for cryopreservation. Sperm motility requirements according to SNI standard is at $70 \%$ for individual motility and for mass motility was ++ . The spermatozoa viability found in this research was higher compared to the finding by Effendi et al. (2015), which shown spermatozoa viability of $83.64 \pm$ $7.85 \%$.

\section{Before Freezing and Post-thawed Sperm Qualities}

The progressive sperm motility, viability, plasm membrane integrity in this research was observed both on pre-freezing and post-thawed, and the results is presented in Table 2 
Table 2. Mean motility, viability, plasma membrane integrity of bull semen with different soybean extract supplementation levels to tris-egg yolk extender

\begin{tabular}{lcccc}
\hline Parameter & T0 & T1 & T2 & T3 \\
\hline Motility & & & & \\
Before freezing (\%) & $63.40 \pm 4.21^{\mathrm{a}}$ & $63.62 \pm 4.331^{\mathrm{a}}$ & $65.00 \pm 2.42^{\mathrm{b}}$ & $63.55 \pm 3.51^{\mathrm{a}}$ \\
Post-thawed (\%) & $52.21 \pm 0.00^{\mathrm{a}}$ & $52.32 \pm 0.00^{\mathrm{ab}}$ & $55.30 \pm 2.42^{\mathrm{c}}$ & $52.50 \pm 2.64^{\mathrm{b}}$ \\
Viability & & & \\
Before freezing (\%) & $70.24 \pm 6.69^{\mathrm{a}}$ & $70.96 \pm 6.44^{\mathrm{b}}$ & $72.43 \pm 6.18^{\mathrm{c}}$ & $70.28 \pm 7.51^{\mathrm{b}}$ \\
Post-thawed (\%) & $60.23 \pm 5.31^{\mathrm{a}}$ & $60.22 \pm 4.12^{\mathrm{a}}$ & $62.12 \pm 4.58^{\mathrm{c}}$ & $61.12 \pm 4.40^{\mathrm{b}}$ \\
Plasma membrane & & & & \\
integrity & & & & \\
Before freezing (\%) & $69.16 \pm 5.39^{\mathrm{a}}$ & $69.34 \pm 6.03^{\mathrm{b}}$ & $71.82 \pm 7.37^{\mathrm{c}}$ & $69.98 \pm 6.91^{\mathrm{b}}$ \\
Post-thawed (\%) & $60.14 \pm 6.21^{\mathrm{a}}$ & $60.82 \pm .12^{\mathrm{ab}}$ & $64.32 \pm 6.15^{\mathrm{c}}$ & $61.31 \pm 6.25^{\mathrm{b}}$ \\
\hline Desction
\end{tabular}

Description: Different superscripts on the same row indicate significant differences $(\mathrm{P}<0.05)$

The finding of this research showed that the supplementation of soybean extract to Tris extender at various concentration levels could maintain progressive sperm motility, with the best value was found at $10 \%$ (T2) soybean extract concentration level. Furthermore, the overal post-thawed progressive motility of Simmental semen in this research was at $52.21 \%$ to $55.30 \%$, which has fulfilled the Indonesian national standard that was set at $>40 \%$ as written in SNI 4869-1:2017 regulation.

The decreased post-thawed progressive motility compared to the fresh semen was due to the cold shock experienced by the spermatozoa. The cold shock would be able to damage the spermatozoa, thus a protection toward cold shock should be done for successful insemination. The supplementation of soybean extract in this reseach has shown the protective effect toward cold shock, which can be seen from higher progressive motility of all research treatments compared to the control. The results were due to the low-density lipoprotein content in soybean extract, which act as protective agent against cold shock.

The anti cold shock compounds are mainly found on egg yolk (animal-based lecithin) and soybean (plant-based lecithin). The addition of lecithin on semen extender would form a coating which would maintain phospholipid bilayer structure of the spermatozoa (Rezki et al., 2016), thus preventing cell damage caused by the cold shock. Moreover, research also found that the phospholipid compounds from the egg yolk and lecithin from soybean extract would form a protective coating against extracelullar cold shock or other physical damage during freezing to thawing (Ariantie et al., 2013).

The sperm viability is also one of the important indicators to determine semen quality. The viability observation in this research showed that soybean extract supplementation to Tris extender gave significant effect $(\mathrm{P}<0.05)$ both on prefreezing and post-thawed. The decreased viability of frozen semen on semen cryopreservation was caused by extreme temperature changes, which then disrupted plasma membrane of the spermatozoa (Priyanto et al., 2015). Plasma membrane act as protective agent for the spermatozoa towards external damage, and the disrupted plasma membrane indicate damaged spermatozoa head and would be stained during staining observation.

During cold shock, post-thawed viability of the spermatozoa would be decreased as reactive oxygen species (ROS) would be produced due to the cooling rate. Moreover, electrolytes concentration would be increased and dilute lipoprotein compounds on the spermatozoa cell wall during thawing, resulted with alteration on 
cell membrane permeability and followed with dead spermatozoa cell (Hoesni, 2016). The supplementation of soybean extract at $10 \%(\mathrm{v} / \mathrm{v})$ to Tris aminomethane-egg yolk extender in this research showed the best ability to maintain spermatozoa viability. Noviansyah et al. (2017) elucidate that soybean could protect plasmic membrane of the spermatozoa during cryopreservation due to the phosphatidicholin compound that would act as coating to maintain lipid bilayer configuration of the spermatozoa.

Other research also showed that the supplementation of soybean extract to citrate extender could increase spermatozoa viability and prevent necrosis of Sapudi goat semen (Immelda et al., 2019). Zhang et al. (2009) added that the addition of $6 \%$ soybean lecithin to the semen extender showed the best spermatozoa motility and plasma membrane integrity in frozenthawed boar spermatozoa.

The phospholipids in soybean lecithin may be replaced the phospholipids of the sperm membrane and maintain the structure and function of spermatozoa. Research by Tarig et al. (2017) showed that 1.5\% soybean lecithin supplementation to $2 \%$ VCO Tris-based extender improve the bull semen qualities, even though there was no improvement to the post-thawed semen qualities.

The analysis of variance showed that the supplementation of soybean extract to the Tris extender had significant effect $(\mathrm{P}<0.05)$ to maintain plasma membrane integrity of post-thawed Simmental semen. The research also found that the best postthawed membrane integrity was at $10 \%$ (T2) soybean extract supplementation. This indicates that $10 \%$ soybean extract supplementation to Tris extender was optimum to maintain plasma membrane integrity of frozen Simmental semen. Mondal et al. (2010) reported that the cryopreservation could reduce spermatozoa membrane integrity up to $25 \%$.

The finding in this research is higher compared to Ariantie et al. (2013) that showed $54.14 \%$ membrane integrity with the utilization of glycerol and dimethylformamida as cryoprotectant. The plasma membrane integrity was reduced during cryopreservation due to the lipid peroxidation which damage the membrane structure. Moreover, the thawing of frozen semen alters protein activity and membrane permeability. One of the main factors which disrupt plasma membrane cell integrity is the formation of ice crystals during cryopreservation (Carreira et al., 2013). Semen cryopreservation, which was done at $-196^{\circ} \mathrm{C}$ would induce cold shock to the spermatozoa.

The effort to suppress the plasma membrane damage could be done by providing extracelullar cryoprotectants, such as lecithin and lipoproteins. The supplementation of soybean extract to semen extender is aimed to provide lecithin which protect the plasma membrane from cold shock. The similar properties were also found on low density lipoproteins from egg yolk. Other research also showed that soybean extract supplementation to semen extender could provide cryoprotection for the spermatozoa, thus maintain its membrane integrity (Pamungkas and Krisnan, 2017).

Reactive oxygen species (ROS) also known to affect spermatozoa membrane integrity during cryopreservation. The ROS would be formed during cryopreservation, and at high concentration level, the ROS would cause extreme oxidative stress. The oxidative reaction then alters polyunsaturated fatty acids on spermatozoa membrane and damage the cell. In order to prevent this oxidative reaction, research by Lone et al. (2019) showed that antioxidants can be added to the semen extender.

This elucidate the better plasma membrane integrity of frozen semen with soybean extract supplementation of this research. Wahjuningsih et al. (2019) added that antioxidant compounds could prevent lipid peroxide chain reactions by the free radicals which damage plasma membrane integrity. 
The natural antioxidants from fenolic compounds are categorized as secondary metabolites produced by plant. Moreover, soybean also contains isoflavon, genistein and daidzein (Asih, 2009) and lecithin, a phospholipid compounds that could prevent damage to the spermatozoa plasma membrane during extension, cooling, and cryopreservation (Layek et al., 2016). In this research, it is found that $10 \%(\mathrm{v} / \mathrm{v})$ soybean extract supplementation to tris-egg yolk extender showed the best result on maintaining post-thawed Simmental bull semen quality, whether on spermatozoa motility, viability, plasma membrane integrity.

The supplementation more than $10 \%$ (v/v) showed negative result. The result was due to the excess antioxidant supplementation from the soybean extract, which could reduce spermatozoa progressive motility, viability, and plasma membrane integrity as well. Execessive antioxidant supplementation could damage the plasma membrane by altering the osmolality of semen extender. Thus, a sufficient antioxidant supplementation level should be taken into consideration so that semen quality could be maintained by inhibiting ROS activity (Partyka et al., 2012) without altering the osmolality of semen extender.

\section{CONCLUSIONS}

The supplementation of soybean (Glycine $\max$ (L.) Merr.) to Tris aminomethane-egg yolk extender showed significant effect on the post-thawed quality of Simmental bull semen. The soybean extract supplementation at $10 \% \quad(\mathrm{v} / \mathrm{v})$ showed the best ability to maintain postthawed semen quality.

\section{ACKNOWLEDGEMENTS}

We would like to thank Insemination Center Ungaran for facilitating this research.

\section{REFERENCES}

Ariantie, O. S., Yusuf, T. L., Sajuthi, D., \& Arifiantini, R. I. (2013). Effect of glycerol and dimethylformamide (DMF) cryoprotectants on buck Etawah Crossbreed frozen semen using modified tris diluents. Jurnal Ilmu Ternak Dan Veteriner, 18(4), 239-250. https://doi.org/10.14334/ji tv.v18i4.327

Arifiantini, R. L. 2012. Teknik Koleksi dan Evaluasi Semen Pada Hewan. Bogor, Indonesia: IPB Press.

Asih, I. A. R. A. 2009. Isolasi dan identifikasi senyawa isoflavon dari kacang kedelai (Glycine max). Jurnal Kimia, 3(1), 33-40.

Carreira, R. P., Borges, P., Fernnando, M., \& Fontbone, A. (2013). Success in artificial insemination-quality of semen and diagnostics employed: Molecular markers. In A. Lemma (Ed.), Sperm Analysis. Intech Open Science.

Ducha, N., Susilawati, T., Aulanni`am, Wahyunings, S., \& Pangestu, M. (2012). Ultrastructure and fertilizing ability of limousin bull sperm after storage in Cep2 extender with and without egg yolk. Pakistan Journal of Biological Sciences, 15(20), 979-985. https://doi.org/10.3923/ pjbs.2012.979.985

Effendi, F., Wahjuningsih, S., \& Ihsan, M. N. (2015). Pengaruh pengencer Tris Aminomethane kuning telur yang disuplementasi sari kulit Manggis (Garcinia Mangostana) terhadap kualitas semen Sapi Limousin selama penyimpanan suhu dingin 50C. Jurnal Ilmu-Ilmu Peternakan, 25(3), 69-79. https://doi.org/10.21776/ub.jiip.2015. 025.03.09

Hoesni, F. (2016). Pengaruh penggunaan tris dalam pengencer susu skim terhadap resistensi spermatozoa sapi Simmental pasca pembekuan. Jurnal Ilmu-Ilmu Peternakan, 19(2), 77-82. https://doi. org/10.22437/jiiip.v19i2.3850

Immelda, K. H., Susilowati, S., Yudaniayanti, I. S. 2019. The effect of soya bean (Glycine max) extractin sperm diluter to the sperm viability and necrosis in Sapudi ram. Ovozoa, 
8(1), 36-42.

Ismaya. 2014. Bioteknologi Inseminasi Buatan Pada Sapi dan Kerbau. Yogyakarta, Indonesia: Gajah Mada University Press.

Karunakaran, M., \& Devanathan, T. G. (2017). Evaluation of bull semen for fertility-associated protein, in vitro characters and fertility. Journal of Applied Animal Research, 45(1), 136144. https://doi.org/10.1080/0971211 9.2015.1129343

Layek, S. S., Mohanty, T. K., Kumaresan, A., \& Parks, J. E. (2016). Cryopreservation of bull semen: Evolution from egg yolk based to soybean based extenders. Animal Reproduction Science, 172, 1-9. https://doi.org/10.1016/j.anireprosci.2 016.04 .013

Lone, F. A., Naikoo, M., Khatun, A., Shah, R. A., Pampori, Z. A., Khan, H. M., \& Ahanger, A. A. (2019). Idebenone improves quality of ram sperm by mitigating oxidative stress during cryopreservation. Cryobiology, 90(1), 15-20. https://doi.org/10.1016/j.cryo biol.2019.09.004

Lukman, H. Y., Busono, W., Wahyuningsih, S., \& Suyadi, S. (2014). Sperm motility and viability after $\alpha$ tocopherol dilution in Tris Aminomethane-base extender during cold storage in Bali bull. International Journal of ChemTech Research, 6(14), 5726-5732.

Mondal, M., Karunakaran, M., Lee, K.-B., \& Rajkhowa, C. (2010). Characterization of Mithun (Bos frontalis) ejaculates and fertility of cryopreserved sperm. Animal Reproduction Science, 118(2-4), 210 216. https://doi.org/10.1016/j.anirepro sci.2009.09.001

Noviansyah, L., Tjandrakirana, T., \& Ducha, N. (2017). Pengaruh penambahan soya dalam buffer dasar Tris-Citric Acid-Fructose (TCF) terhadap motilitas spermatozoa kambing Boer pasca pembekuan.
LenteraBio, 6(1), 23-26.

Pamungkas, F. A., \& Krisnan, R. (2017). Pemanfaatan sari kedelai sebagai bahan pengencer pengganti kuning telur untuk kriopreservasi spermatozoa hewan. Jurnal Penelitian Dan Pengembangan Pertanian, 36(1), 21-27. https://doi.org/10.21082/jp3.v 36n1.2017.p21-27

Partyka, A., Łukaszewicz, E., \& Niżański, W. (2012). Lipid peroxidation and antioxidant enzymes activity in avian semen. Animal Reproduction Science, 134(3-4), 184-190. https://doi.org/10. 1016/j.anireprosci.2012.07.007

Priyanto, L., Arifiantini, R. I., \& Yusuf, T. L. (2015). Deteksi kerusakan dna spermatozoa semen segar dan semen beku sapi menggunakan pewarnaan toluidine blue. Jurnal Veteriner, 16(1), 48-55.

Rahayu, W., Agung, P. W. M., \& Ciptadi, G. (2014). Kualitas semen segar kambing Boer pada temperatur penyimpanan $4^{\circ} \mathrm{C}$ dengan menggunakan pengencer sitrat dan suplementasi susu kedelai bubuk. Jurnal Biotropika, 2(1), 55-60.

Rezki, Z. M., Samsudewa, D., and Ondho, Y. S. 2016. Pengaruh buffer kombinasi sari kedelai dan Tris terhadap kualitas mikroskopis spermatozoa pejantan sapi PO Kebumen. Jurnal Sain Peternakan Indonesia, 11(2), 67-74.

Tarig, A. A., Wahid, H., Rosnina, Y., Yimer, N., Goh, Y. M., Baiee, F. H., Khumran, A. M., Salman, H., Assi, M. A., \& Ebrahimi, M. (2017). Effect of different concentrations of soybean lecithin and virgin coconut oil in Trisbased extender on the quality of chilled and frozen-thawed bull semen. Veterinary World, 10(6), 672-678. https://doi.org/10.14202/vetworld.201 7.672-678

Wahjuningsih, S., Ciptadi, G., Ihsan, M. N., Isnaini, N., \& Rahayu, S. (2019). Supplementation of Moringa oleifera leaves' extract in Tris-egg yolk extender on the quality and fertility of 
cryopreserved Senduro goat sperm. Livestock Research for Rural Development, 31(12), 1-9.

Zhang, S., Hu, J., Li, Q., Jiang, Z., and Zhang, X. 2009. The cryoprotective effects of soybean lecithin on boar spermatozoa quality. African Journal of Biotechnology, 8(22), 6476-6480 